\title{
PENGEMBANGAN BUKU AJAR BAHASA JEPANG KEPERAWATAN UNTUK SISWA KELAS X SEMESTER GANJIL JURUSAN KEPERAWATAN SMK KESEHATAN VIDYA USADHA SINGARAJA
}

\author{
Bagiasa,W1, Mardani, D.M.S. ${ }^{2}$, Sadyana, W. ${ }^{3}$ \\ Program Studi Pendidikan Bahasa Jepang \\ Universitas Pendidikan Ganesha \\ Singaraja, Bali \\ e-mail:wayanbagiasa@gmail.com,wayan.sadyana@undiksha.ac.id, \\ desakmardani@undiksha.co.id
}

\begin{abstract}
Abstrak
Penelitian ini bertujuan untuk menghasilkan buku ajar yang sesuai dengan kurikulum dan silabus mata pelajaran bahasa Jepang di SMK Kesehatan Vidya Usadha Singaraja untuk kelas X semester ganjil jurusan keperawatan. Penelitian ini merupakan jenis penelitian pengembangan (research and development). Penelitian ini dilaksanakan dengan menggunakan rancangan 4-D models. Subjek dalam penelitian ini adalah guru mata pelajaran bahasa Jepang di SMK Kesehatan Vidya Usadha Singaraja. Pengumpulan data dalam penelitian ini dilakukan dengan wawancara, angket dan dokumentasi. Data dianalisis secara deskriptif kualitatif. Hasil penelitian ini menunjukkan bahwa (1) berdasarkan hasil wawancara yang dilakukan dengan guru mata pelajaran bahasa Jepang di SMK Kesehatan Vidya Usadha Singaraja ditemukan masalah yaitu belum terdapat buku ajar bahasa Jepang yang sesuai dengan kebutuhan siswa khususnya untuk siswa kelas X semester ganjil jurusan keperawatan. (2) Buku ajar ini menghasilkan materi bahasa Jepang di bidang kesehatan. (3) Berdasarkan angket ahli isi materi, buku ajar yang dibuat sangat sesuai.
\end{abstract}

Kata kunci: Bahasa Jepang, buku ajar, keperawatan, penelitian dan pengembangan.

要旨

本研究は、シンガラジャウィディアウサダ保健医療害業高等学校看護コース 10 年前期生が、日本語授 業で使用寸る教科書を作成寸る調査開発研究であり、4-Dモデル計画によるものである。対象は、同 校日本語科日本語指導教師である。データは、インタビュー、アンケート、録画により修集し、定性 的記述法により分析した。結果、(1) 同校日本語指導教師へのインタビュー及びアンケートで、同校 看護コース 10 年前期で目的に適して使用できる日本語教科書が、未だ存在しないことが判明した。 （2）作成した日本語教科書の内容は、看護コースに適したものである。（3）。アンケートによると、 作った教科書通いである。

キーワード：日本語、教科書、看護、研究と開発

\section{Pendahuluan}

Di Indonesia banyak sekolah-sekolah SMK yang saat ini didirikan. Sekolah SMK memiliki tujuan untuk menyiapkan peserta didiknya memiliki keahlian dan keterampilan tertentu dan siap bekerja sesuai dengan bidang kompetensi keahliannya. Hal tersebut sesuai dengan undang-undang nomor 2 sistem pendidikan nasional yang menyebutkan bahwa "Pendidikan Kejuruan merupakan pendidikan yang mempersiapkan peserta didik untuk dapat bekerja dalam bidang tertentu".

Keterampilan yang dimaksud adalah keterampilan dalam berbahasa asing sesuai dengan kejuruan setiap sekolah seperti bahasa asing dalam bidang perhotelan, kesehatan dan yang lainya. Bahasa Jepang merupakan salah satu bahasa asing yang dipelajari di sekolah-sekolah. Penggunaan bahasa Jepang untuk pelajar SMK kesehatan maupun perhotelan dirasa sangat penting karena semakin dibutuhkannya tenaga-tenaga kerja yang tidak hanya mahir dibidangya masing-masing tetapi juga dapat berkomunikasi secara lebih luas, termasuk berkomunikasi dalam bahasa Jepang. 
SMK Kesehatan Vidya Usadha Singaraja merupakan sekolah yang berada di kawasan Singaraja Bali dan beralamat di Kecamatan Sukasada yang berdiri sejak tahun 2009. SMK Kesehatan Vidya Usadha Singaraja merupakan SMK keperawatan yang mendapatkan pembelajaran bahasa Jepang. Kurikulum yang digunakan masih KTSP (Kurikulum Tingkat Satuan Pendidikan). Menurut departemen pendidikan nasional (Sudira 2006) kurikulum tingkat kesatuan pendidikan adalah kurikulum oprasional yang disusun oleh dan dilaksanakan di masing-masing satuan pendidikan. SMK Kesehatan Vidya Usadha Singaraja merupakan sebuah SMK yang mendukung perkembangan mata pelajaran bahasa asing dengan membantu siswanya memiliki kualitas ilmu pengetahuan bahasa Jepang yang sesuai dengan kejuruannya yaitu bahasa Jepang kesehatan. Kelebihan SMK Kesehatan Vidya Usadha Singaraja adalah SMK dalam bidang keperawatan yang mampu langsung mempekerjakan siswanya dibeberapa rumah sakit. Kekurangannya yaitu minimnya pembelajaran bahasa asing khususnya pembelajaran bahasa Jepang kesehatan, sehingga kecil kemungkinannya dirasa bagi lulusan SMK Kesehatan Vidya Usadha Singaraja sebagai tenaga kesehatan berwawasan internasional.

Berdasarkan hasil wawancara yang dilakukan oleh peneliti kepada guru pengampu mata pelajaran bahasa Jepang diketahui bahwa dalam pembelajaran bahasa Jepang siswa sangat antusias dalam menerima materi, namun permasalahan yang dialami adalah kurangnya bahan ajar yang sesuai dengan bidang kejuruan di SMK Kesehatan Vidya Usadha Singaraja. Berdasarkan hasil kuesioner, siswa sendiri menyatakan buku yang digunakan dalam proses pembelajaran adalah buku Sakura yang merupakan buku ajar yang materinya masih bersifat umum, tidak menjurus kearah bidang kesehatan. Selain itu, hasil wawancara menunjukan bahwa sekolah telah mendapatkan tawaran dari pihak luar untuk bekerja di Jepang sebagai perawat bagi siswa lulusan SMK Kesehatan Vidya Usadha Singaraja, namun karena minimnya pengetahuan siswa tentang bahasa Jepang kesehatan yang disebabkan oleh bahan ajar yang tidak memadai, sehingga tawaran tersebut tidak bisa diterima oleh pihak sekolah. Kemudian berdasarkan hasil angket sebagian besar siswa menginginkan buku ajar bahasa Jepang kesehatan dasar.

Terkait permasalahan ini, telah terdapat penelitian sejenis yang sudah dikembangkan. Penelitian sejenis tersebut adalah penelitian Research and Development, membuat buku ajar keperawatan. Asmaniah (2017), yang membuat buku ajar bahasa Jepang keperawatan untuk siswa kelas X semester genap jurusan keperawatan SMK Kesehatan Vidya Usadha Singaraja.

Pada setiap bab di buku ini dilengkapi dengan penyajian pengantar, kosakata yang dilengkapi dengan gambar, pola kalimat, latihan dasar, kegiatan yang digunakan untuk berlatih di kelas, kemudian tugas yang diberikan untuk melatih kembali pembelajaran yang sudah diberikan sebelumnya. Selain itu, terdapat latihan menulis huruf Katakana. Kemudian pada buku ajar bahasa Jepang keperawatan setelah 3 bab terdapat fukushuu (latihan).

Selain itu, pengembangan mengenai buku ajar pernah dilakukan oleh Pratama (2016) yang membuat buku ajar bahasa Jepang perhotelan untuk siswa kelas XI jurusan akomodasi perhotelan SMK Nusa Dua Sawan. Dalam produk yang dibuat oleh Pratama (2016) dipaparkan mengenai cara berkomunikasi antara pengunjung dan petugas hotel.

Penelitian sejenis yang selanjutnya adalah penelitian oleh Riani (2014), yang membuat buku bergambar bahasa Jepang tingkat pemula untuk kelas 1 di SD 3 Saraswasti Denpansar.

Buku ajar bahasa Jepang keperawatan ini perlu dikembangakan karena pada buku ajar bahasa Jepang yang digunakan sebelumnya yaitu buku Sakura tidak sesuai dengan karakteristik siswa dan jurusan keperawatan yang terdapat di SMK Kesehatan Vidya Usadha Singaraja. Buku Sakura merupakan buku yang diperuntukan untuk sekolah umum atau SMA, sehingga materi yang terdapat pada buku Sakura tidak sesuai dengan jurusan keperawatan yang ada di SMK Kesehatan Vidya Usadha Singaraja.

Buku ajar bahasa Jepang keperawatan 1 sebagai dasar pembelajaran bahasa Jepang untuk siswa kelas $X$ semester ganjil. Konsep buku ajar dirancang bersama guru mata pelajaran bahasa Jepang di SMK Kesehatan Vidya Usadha Singaraja agar sesuai dengan kebutuhan siswa dan metode yang digunakan oleh guru pengampu mata pelajaran bahasa Jepang.

Berdasarkan kenyataan yang dialami oleh SMK Kesehatan Vidya Usadha Singaraja yaitu belum adanya bahan ajar kesehatan bahasa Jepang, maka buku yang hendak 
dikembangkan peneliti berupa buku bahasa Jepang keperawatan kelsa $X$ untuk siswa semester ganjil di SMK Kesehatan Vidya Usadha Singaraja. Dengan adanya buku ajar kesehatan dasar ini siswa yang bersekolah di SMK Kesehatan Vidya Usadha Singaraja (kelas X) merasa terbantu dalam proses pembelajaran bahasa Jepang. Penelitian ini diharapkan memberikan pemecahan karena buku ajar keperawatan bahasa Jepang dasar yang dihasilkan nanti tidak hanya bermanfaat untuk sekolah SMK Kesehatan Vidya Usadha Singaraja tetapi juga untuk SMK kesehatan yang lain.

\section{Metode}

Penelitian ini merupakan research and development (R\&D) yakni pengembangan buku ajar bahasa Jepang kesehatan dasar. Dalam penelitian ini menggunakan pendekatan kualitatif. Pendekatan kualitatif adalah prosedur penelitian yang menghasilkan data deskriptif berupa kata-kata tertulis maupun lisan dari orang-orang dan perilaku yang diamati. Dalam penelitian ini merupakan penelitian tahap awal yaitu penyusunan buku ajar bahasa Jepang kesehatan dasar kelas $X$ yang disesuaikan dengan karakteristik dan kebutuhan dari SMK Kesehatan Vidya Usadha Singaraja

Prosedur pada penelitian ini dilakukan dengan menggunakan rancangan $R \& D$ dengan menggunakan Four-D Model. Menurut Thiagarajan, dkk Four-D model ini terdiri dari 4 tahap pengembangan, yaitu Define, Design, Develop, dan Disseminate atau diadaptasikan menjadi model 4-D, yaitu pendefinisian, perancangan, pengembangan, dan penyebaran.

Pada tahap Define (Pendefinisian) untuk menetapkan dan mendefinisikan syarat-syrat pembelajaran yang mencangkup lima langkah pokok, yaitu analisis ujung depan, analisis pelanggan, analisis konsep, analisis tugas, dan perumusan tujuan pembelajaran. Pada penelitian ini, tahap define akan dilakukan wawancara terhadap guru mata pelajaran bahasa Jepang di SMK Kesehatan Vidya Usadha Singaraja untuk analisis terhadap kebutuhan dari buku ajar bahasa Jepang kesehatan yang akan dikembangkan. Kemudian akan dilakukan analisis terhadap kurikulum serta silabus yang digunakan untuk menyesuaikan kebutuhan guru dengan silabus dan kurikulum di sekolah SMK Kesehatan Vidya Usadha Singaraja. Setelah itu, penentuan tema pada buku yang akan dikembangkan untuk mencapai standar kompetensi dan kompetensi dasar. Dalam tahap ini penulis mencari masalah dasar apa yang dihadapi dalam pembelajaran dan mendeskrifsikan dengan 5 langkah pokok pada tahan Define.

1. Analisis Ujung Depan (front-end analysis)

Menurut Thiagarajan, dkk (1974), analisis ujung depan bertujuan untuk memunculkan dan menetapkan masalah dasar yang dihadapi dalam pembelajaran, sehingga diperlukan suatu pengembangan bahan ajar. Dengan analisis ini akan didapatkan gambaran fakta, harapan dan alternatif penyelesaian masalah dasar, yang memudahkan dalam penentuan atau pemilihan bahan ajar yang dikembangkan.

Analisis ujung depan di awali dari pengetahuan, keterampilan, dan bahan ajar yang digunakan untuk meningkatkan efektipitas pembelajaran. Pada tahap akhir analisis ini akan didapatkan gambaran fakta, harapan dan alternatif penyelesaian masalah dasar yang memudahkan dalam penentuan atau pemilihan bahan ajar yang akan dikembangkan.

2. Analisis Pelanggan (customer analysis)

Menurut Thiagarajan, dkk (1974), analisis pelanggan merupakan telaah tentang karakteristik pelanggan yang sesuai dengan desain pengembangan perangkat pembelajaran. Karakteristik itu meliputi latar belakang kemampuan akademik (pengetahuan), perkembangan kognitif, serta keterampilan-keterampilan individu atau sosial yang berkaitan dengan buku panduan, media, format dan bahasa yang dipilih. Analisis pelanggan dilakukan untuk mendapatkan gambaran karakteristik pelanggan, antara lain: (1) tingkat kemampuan atau perkembangan intelektualnya, (2) keterampilan individu atau sosial yang sudah dimiliki dan dapat dikembangkan untuk mencapai tujuan pembelajaran yang ditetapkan.

Analisis siswa dilakukan untuk mengetahui komponen isi buku yang akan disesuaikan dengan standar kemampuan pengetahuan, akademik, serta keterampilan. Sehingga nantinya buku yang dikembangkan akan sesuai dengan karakteristik siswa di SMK Kesehatan Vidya Usadha Singraja. 


\section{Analisis Konsep (concept analysis)}

Analisis konsep menurut Thiagarajan, dkk (1974), dilakukan untuk mengidentifikasi konsep pokok yang akan diajarkan, menyusunnya dalam bentuk hirarki, dan merinci konsepkonsep individu ke dalam hal yang kritis dan yang tidak relevan. Analisis membantu mengidentifikasi kemungkinan contoh dan bukan contoh untuk digambarkan dalam mengantar proses pengembangan. Analisis konsep sangat diperlukan guna mengidenfikasi pengetahuan-pengetahuan deklaratif atau prosedural pada materi yang akan dikembangkan. Analisis konsep merupakan satu langkah penting untuk memenuhi prinsip kecukupan dalam membangun konsep atas materi-materi yang digunakan sebagai sarana pencapaian kompetensi dasar dan standar kompetensi. Mendukung analisis konsep ini, analisis-analisis yang perlu dilakukan adalah (1) analisis standar kompetensi dan kompetensi dasar yang bertujuan untuk menentukan jumlah dan jenis buku ajar, (2) analisis sumber buku ajar, yakni mengumpulkan dan mengidentifikasi sumber-sumber mana yang mendukung penyusunan buku ajar.

Analisis konsep dilakukan untuk mengidentifikasi pengetahuan deklaratif atau prosedural. Ini di lakukan untuk memenuhi prinsip kacakupan dalam konsep atau materi-materi dalam pencapaian standar kompetensi dan kompetensi dasar. Untuk mendukung analisis konsep ini, analisis-analisis yang perlu dilakukan adalah analisis standar kompetensi dan kompetensi dasar yang bertujuan untuk menentukan jumlah dan jenis bahan ajar, analisis sumber belajar, yakni mengumpulkan dan mengidentifikasi sumber-sumber mana yang mendukung penyusunan bahan ajar.

4. Analisis Tugas (task analysis)

Analisis tugas menurut Thiagarajan, dkk (1974), bertujuan untuk mengidentifikasi keterampilan-keterampilan utama yang akan dikaji oleh peneliti danmenganalisisnya ke dalam himpunan keterampilan tambahan yang mungkin diperlukan. Analisis ini memastikan ulasan yang menyeluruh tentang tugas dalam materi buku ajar. Analisis ini memastikan ulasan yang menyeluruh tentang tugas dalam materi pembelajaran.

5. Perumusan Tujuan (specifying objectives)

Perumusan tujuan pembelajaran menurut Thiagarajan, dkk (1974), berguna untuk merangkum hasil dari analisis konsep dan analisis tugas untuk menentukan perilaku objek penelitian. Kumpulan objek tersebut menjadi dasar untuk menyusun dan merancang buku ajar yang kemudian diintegrasikan ke dalam materi buku pembelajaran yang akan dikembangkan oleh peneliti.

Pada tahap Design (Perancangan) bertujuan untuk merancang buku yang dikembangkan pada penelitian ini. Pada tahap ini menggunakan empat langkah yang harus dilakukan (1) penyususnan tes acuan patokan (criterrion-test contruction), (2) pemilihan media (media selection) yang sesuai dengan karakteristik materi dan tujuan pembelajaran, (3) pemilihan format (format selection), yakni menganalisis format-format bahan ajar yang ada dan menetapkan format bahan ajar yang akan dikembangkan, dan (4) membuat rencana awal (innitial design) sesuai format yang dipilih. Pada tahap ini peneliti membuat kerangka isi buku sesuai dengan hasil yang didapatkan pada tahap Define. Adupun langkah-langkahnya sebagai berikut:

1. Penyusunan standar tes (Criterion-test Construction)

Menurut Tiagarajan, dkk (1974), penyusunan standar tes merupakan langkah yang menghubungkan antara tahap pendefinisian (difine) dengan tahap perancangan (design). Menyusun tes kriteria, Tindakan pertama untuk mengetahui kemampuan awal siswa dan sebagai alat evaluasi setelah implementasi kegiatan. Tes acuan patokan disusun berdasarkan spesifikasi tujuan pembelajaran dan analisis siswa, kemudian selanjutnya disusun kisi-kisi tes hasil belajar. Tes yang dikembangkan disesuaikan dengan jenjang kemampuan kognitif. Penskoran hasil tes menggunakan panduan evaluasi yang memuat kunci dan pedoman penskoran setiap butir soal.

2. Pemilihan media (Media Selection)

Menurut Tiagarajan, dkk dkk (1974), Pemilihan media dilakukan untuk mengidentifikasi media pembelajaran yang relevan dengan karakteristik materi. media dipilih untuk menyesuakan dengan analisis konsep dan analisis tugas, karakteristik target pengguna, serta 
rencana penyebaran dengan atribut yang bervariasi dari media yang berbeda-beda. Hal ini berguna untuk membantu siswa dalam pencapaian kompetensi dasar. Artinya pemilihan media dilakukan untuk mengoptimalkan penggunaan bahan ajar dalam proses pengembangan bahan ajar pada pembelajaran di kelas.

3. Pemilihan format (Format Selection)

Pemilihan format dalam pengembangan perangkat pembelajaran ini menurut Tiagarajan, dkk dkk (1974), dimagsudkan untuk mendesain atau merancang isi pembelajaran, pemilihan strategi, pendekatan, metode pembelajaran, dan sumber belajar. Format yang dipilih adalah yang memenuhi kriteria yang menarik, memudahkan dan membantu dalam pembelajaran. Pemilihan bentuk penyajian pembelajaran disesuaikan dengan media pembelajaran yang digunakan.

4. Rancangan Awal (Initial Design)

Menurut Tiagarajan, dkk dkk (1974), "initial design is the presenting of the essential instruction through appropriate media and in a suitable sequence". Rancangan awal yang dimagsud adalah rancangan seluruh perangkat pembelajaran yang harus dikerjakan sebelum uji coba dilaksanakan. Hal ini juga meliputi berbagai aktivitas pembelajaran yang terstruktur seperti membaca teks, wawancara, dan praktek kemampuan pembelajaran yang berbeda melalui praktek mengajar.

Pada tahap Develop (pengembangan) memiliki dua langkah yaitu validasi ahli atau praktisi (expert appraisal) dan uji coba pengembangan (developmental testing). Pada tahap ini peneliti melakukan penilaian ahli untuk menghasilkan bentuk akhir setelah melalui revisi berdasarkan masukan pakar ahli atau praktisi dan hasil uji coba terbatas kepada siswa dengan memperlihatkan produk yang sudah di revisi oleh pakar ahli.

Tujuan tahap pengembangan ini adalah untuk menghasilkan bentuk akhir buku ajar setelah melalui revisi berdasarkan masukan para pakar ahli atau praktisi dan data hasil uji coba terbatas.

Menurut Thiagarajan, dkk (1974), tahap Dissiminte (penyebaran) adalah tahap akhir pengembangan produk. Pada tahap penyebaran bertujuan untuk memperomosikan produk agar produk bisa berterima. Dalam tahap penyebaran dilakukan tiga kegiatan diantaranya adalah validation testing, packaging, diffusion and adoption. Pada tahap Dissiminte tidak dilakukan karena keterbatasan waktu penelitian.

Berdasarkan tahap develop diperlukan uji coba lapangan yang dilakukan untuk memperoleh masukan langsung berupa respon, reaksi, komentar siswa dan para pengamat terhadap perangkat pembelajaran yang telah disusun. Menurut Thiagarajan, dkk (1974) uji coba, revisi dan uji coba kembali terus dilakukan hingga diperoleh perangkat yang konsisten dan efektif.

Subjek uji coba pada produk pada penelitian ini adalah dosen bahasa Jepang di jurusan pendidikan bahasa Jepang yang akan membantu memberikan saran mengenai isi materi bahasa Jepang, karena buku yang peneliti kembangkan diperuntukan untuk bidang kesehatan yang materinya termasuk pada level sulit. Kemudian uji ahli untuk membantu memberikan saran mengenai desain dari buku.

Jenis data pada penelitian ini adalah data skala kecil menggunakan angket, hasil wawancara berupa kata-kata dan dokumentasi berupa gambar. Data dikumpulkan dari para ahli materi bahasa Jepang, dosen pendidikan bahasa Jepang dan guru bahasa Jepang di SMK Kesehatan Vidya Usadha Singaraja.

Pada penelitian ini menggunakan tiga instrumen penelitian yang digunakan untuk mengumpulkan data dan menganalisis data yaitu wawancara, angket dan dokumentasi. Wawancara yang dilakukan dalam penelitian ini mengambil guru pengampu mata pelajaran bahasa Jepang di SMK Kesehatan Vidya Usadha Singaraja sebagai respondenya. Wawancara dilakukan dengan tujuan untuk mengetahui permasalahan dan hambatan yang dialami guru dalam mengajar, model instrumen angket adalah tekni pengumpulan data yang melalui formulir yang diajukan secara tertulis kepada reponden untuk mendapatkan jawaban dan informasi yang diperlukan oleh peneliti dan dokumentasi dalam penelitian ini dengan mengambil gambar-gambar yang merujuk ke tempat, benda-benda dan situasi yang 
berhubungan dengan bidang kesehatan yang dibutuhkan pada penyusunan buku ajara bahasa Jepang kesehatan dasar.

Data yang diperoleh dengan instrumen angket/kuesioner pada tahap define dan develop juga dianalisis dengan pendekatan deskriptif kualitatif.

\section{Hasil dan Pembahasan}

Data yang telah terkumpul dari instrumen yang telah diisi oleh responden kemudian ditabulasi. Disesuaikan dengan permasalahan yang hendak dipecahkan melalui penelitian ini dan sifat informasi yang dikumpulkan, maka dari itu analisis data dilakukan dengan meginterpretasi data tersebut dengan dibantu teknik triangulasi. Hal ini bertujuan untuk mengecek kebenaran informasi atau kebenaran data yang diperoleh dari hasil penelitian dari berbagai sudut pandang yang berbeda tentunya dengan cara mengurangi sebanyak mungkin perbedaan yang terjadi pada saat pengumpulan data dan analisis data. Hasil informasi juga disesuaikan denga masalah-masalah yang menjadi fokus penelitian. Hasil penelitian ini disajikan dalam bentuk deskriptif kualitatif yang mengambarkan keadaan objek sebenarnya dengan melalui pemaparan fakta agar bisa dijadikan sebagai simpulan dan rekomendasi.

Dalam mengembangkan buku ajar bahasa Jepang keperawatan yang dibuat untuk memenuhi kebutuhan siswa kelas $X$ semester ganjil jurusan keperawatan di SMK Vidya Usadha Singaraja diperlukan adanya model-model pengembangan yang menjadi patokan dalam mengembangkan sebuah buku ajar, salah satunya adalah Four-D Models.

Tahap pertama yang dilakukan adalah tahap pendefinisian (difine). Menurut Thiagarajan, dkk (1974) tahap pendefinisian merupakan tahap untuk menetapkan dan mendefinisikan syarat-syarat yang dibutuhkan dalam pengembangan pembelajaran. Sesuai dengan hasil wawancara yang dilakukan dengan guru mata pelajaran bahasa Jepang di SMK Kesehatan Vidya Usadha Singaraja adalah SMK yang menambahkan mata pelajaran bahasa Jepang sebagai mata pelajaran tambahan. Guru mata pelajaran bahasa Jepang di SMK Vidya Usadha Singaraja masih mengalami kesulitan karena belum tersedianya buku ajar yang dianggap sesuai dengan kebutuhan siswa di SMK Kesehatan Vidya Usadha Singaraja. Untuk sementara waktu, buku yang digunakan guru sebagai bahan ajar adalah buku Sakura. Guru mata pelajaran bahasa Jepang menjelaskan bahwa materi yang dibahas dalam buku Sakura masih bersifat umum belum sesuai dengan kebutuhan siswa, khususnya untuk siswa kelas $X$ jurusan keperawatan. Guru mata pelajaran bahasa Jepang di SMK Kesehatan Vidya Usadha Singaraja sangat mengharapkan buku yang dikembangkan adalah buku yang menyajikan materi tentang bahasa Jepang kesehatan agar guru dan siswa SMK Kesehatan Vidya Usadha Singaraja memiliki panduan dalam melakukan pembelajaran.

Dalam proses pembelajaran di kelas guru berupaya memberikan penjelasan agar mudah dimengerti dan tidak terkesan membingunkan. Dalam melatih pola kalimat, guru memberikan berbagai macam contoh kalimat yang dijelaskan secara langsung di kelas dengan maksud pemahaman tentang pola kalimat dalam bahasa Jepang dapat siswa kuasai dengan baik. untuk penguasaan kosakata, guru menggunakan bantuan media bergambar dengan tujuan agar siswa dapat lebih mudah memahaminya.

Tahap kedua yang dilakukan adalah Perancangan (Design). Menurut Thiagarajan, dkk (1974) tahap perancangan bertujuan untuk merancang perangkat pembelajaran. Pada tahap ini kegiatan yang dilakukan adalah pemilihan media. Pemilihan dilakukan untuk mengidentifikasi media pembelajaran yang relevan dengan karakteristik materi. Secara umum media yang digunakan oleh guru adalah media kartu gambar. Berpatokan dari hal tersebut maka dalam setiap penyajian kosakata dilengkapi dengan gambar real berwarna agar memudahkan siswa memahami dan menghafal kosakata. Selanjutnya adalah penentuan format. Penentuan format dimaksudkan untuk mendesain atau merancang isi pembelajaran. Berdasarkan hasil wawancara menjelaskan bahwa komponen-komponen yang harus disajikan dalam buku ajar yang dikembangkan adalah pengantar, penyajian kosakata, penyajian pola kalimat, latihan, penyajian contoh percakapan, kegiatan dan cara penulisan huruf Hiragana. Setelah format sudah ditentukan kemudian buku sudah mulai dirancang dengan menerima masukan dari para ahli agar buku siap dicetak dan melaksanakan langkah selanjutnya ke tahap uji ahli. 
Tahap ketiga adalah tahap Pengembangan (Develop). Dalam kegiatan ini dilakukan evaluasi oleh para ahli dalam bidangnya. Saran-saran yang diberikan digunakan untuk memperbaiki materi dan rancangan pembelajaran yang telah disusun. Pada tahap ini buku sudah dicetak kemudian mendapatkan masukan dari para ahli. Tahap uji ahli dilakukan untuk memperbaiki produk agar layak digunakan untuk siswa SMK Kesehatan Vidya Usadha Singaraja khususnya siswa kelas $X$ semester ganjil.

Buku yang dikembangkan adalah buku bahasa Jepang kesehatan yang akan digunakan oleh siswa kelas X Semester ganjil di SMK Kesehatan Vidya Usadha Singaraja jurusan keperawatan. Buku ini memuat materi tentang kegiatan-kegiatan yang sering terjadi di dalam rumah sakit. Pada setiap bab buku ini sudah dilengkapi dengan penyajian kosakata, pola kalimat, latihan kalimat, contoh percakapan, kegitan dan latihan penulisan hiragana. Buku ini dikembangkan untuk 1 semester yang akan dipakai untuk semester ganjil yang terdiri dari 10 bab yang dibuat sesuai dengan silabus dan analisis kebutuhan yang dianalisis melalui hasil wawancara dan hasil angket. Materi pada setiap bab sudah disesuaikan dengan isi dari silabus siswa SMK Kesehatan Vidya Usadha Singaraja kelas X jurusan keperawatan. Adapun 10 materi yang dibahas dalam buku ini yaitu, 1 Aisatsu, 2 Hajimemashite, 3 kenkou, 4 heya no naka hyugen, 5 nihon go den nan desu ka, 6 dare no moufu desu ka, 7 shujutsu-shitus wa doko desu ka, 8 doko ni arimasuka/imasuka, 9 denwa bangou dan 10 karenda.

Sebelum menghasilkan buku yang layak pakai dilakukan tahap uji ahli agar menghasilkan produk buku yang berkualitas dan juga sesuai dengan kebutuhan responden. Buku yang dihasilkan sudah melalui beberapa tahapan perbaikan dengan memperbaiki penggunaan bahasa Jepang yang kurang tepat dan juga perbaikan design buku agar menjadi lebih menarik. Tahap uji ahli dilakukan dengan memberikan angket kepada para ahli agar bisa menilai kelayakan isi buku bahasa Jepang keperawatan yang dikembangkan. Dari hasil angket uji ahli, untuk pertanyaan 1 yaitu tentang tingkat kesesuaian buku ajar dengan kurikulum dan silabus yang berlaku di SMK Kesehatan Vidya Usadha Singaraja. sudah sesuai dengan ketentuan saat uji ahli isi mendapatkan skor "sesuai" dan "sangat sesuai" yang diberikan oleh masing-masing ahli isi yaitu satu dosen Undiksha dan guru mata pelajaran bahasa Jepang di SMK Kesehatan Vidya usadha Singaraja. Untuk pertanyaan 2 yaitu tentang kesesuaian judul dengan isi pada buku "Bahasa Jepang Keperawatan" sudah sesuai dengan alasan karena materi-materi yang disajikan pada buku ini sudah sesuai dengan kebutuhan siswa dan kondisi nyata pada bidang kesehatan, khususnya keperawatan. Tingkat kesesuaian yang diberikan oleh para ahli untuk pertanyaan 2 mendapatkan skor "sesuai" dan "sangat sesuai". Untuk pertanyaan 3 yaitu tentang kesesuaian materi pada buku "Bahasa Jepang Keperawatan" dengan hasil analisis kebutuhan sudah sesuai karena buku ini sudah sesuai dengan keperluan siswa SMK Kesehatan Vidya Usadha Singaraja. Skor yang diberikan oleh para ahli untuk pertanyaan 3 adalah "sesuai" dan "sangat sesuai". Untuk pertanyaan 4 yaitu tentang ketepatan penggunaan bahasa Jepang pada buku ajar "Bahasa Jepang Keperawatan" secara keseluruhan sudah baik dan sangat sederhana (dasar), jadi sesuai dengan pembelajar pemula. Skor yang diberikan oleh para ahli untuk pertanyaan 4 adalah "sangat sesuai" dan "sesuai". Untuk pertanyaan 5 yaitu tentang kemudahan pemahaman penyajian materi pada buku "Bahasa Jepang Keperawatan" sudah bisa dipahami karena penyajiannya sudah dilengkapi dengan contoh kalimat. Skor yang diberikan oleh masing-masing ahli untuk pertanyaan 5 adalah "sesuai". Untuk pertanyaan 6 yaitu kesesuaian latihan pada buku "Bahasa Jepang Keperawatan" sudah sesuai karena sudah disesuaikan dengan silabus. Skor yang diberikan oleh masing-masing ahli untuk pertanyaan 6 adalah "sesuai". Untuk pertanyaan 7 komponen yang disajikan pada buku ini sudah sesuai. Buku ini sudah di bandingkan pada buku ajar sebelumnya. Penggunaan buku sebelumnya menjadi referensi pada penyusunan buku ini. Skor yang diberikan oleh para ahli untuk pertanyaan 7 adalah "sangat sesuai" dan "sesuai". Untuk pertanyaan 8 Kesesuaian Penyajian gambar pada buku ajar sudah dianggap sesuai dan orisinil. Skor yang diberikan oleh para ahli untuk pertanyaan 8 adalah "sangat sesuai" dan "sesuai". Untuk pertanyaan 9 tentang kejelasan penulisan atau pengetikan pada buku ajar "Bahasa Jepang Keperawatan" ini sudah sesuai. Skor yang diberikan oleh masingmasing ahli untuk pertanyaan 9 adalah "sesuai". Untuk pertayaan 10 jenis-jenis kosa kata sesuai dengan penggunaan bahasa Jepang keperawatan sudah sesuai dengan yang 
diperlukan. Skor yan yang berikan dari masing-masing ahli untuk pertayaan 10 adalah "sangat sesuai" dan "sesuai". Untuk pertayaan 11 yaitu tentang penggunaan mudah dipahimi sudah sesuai karena dilengkapi dengan contoh. Skor yang diberikan oleh masing-masing ahli untuk pertayaan 11 adalah "sesuai". Untuk pertanyaan 12 yaitu tentang konsistensi format buku ajar "Bahasa Jepang Keperawatan" sudah konsisten karena penyajian isi pada buku ini dari bab awal sampai akhir sudah konsisten. Skor yang diberikan oleh para ahli untuk pertanyaan 12 adalah "sangat sesuai" dan "sesuai" . Untuk pertanyaan 13 yaitu kemenarikan buku ajar menarik dan konten kreatif karena dilengkapi dengan gambar (foto nyata). Skor yang diberikan oleh para ahli yaitu "sangat sesuai" dan "sesuai". Untuk pertanyaan 14 yaitu kemenarikan pengemasan desain cover sudah sesuai isi dan menarik. Skor yang di berikan oleh masingmasing ahli isi adalah "sangat sesuai" dan "sesuai" .

Buku ini terdiri dari 10 bab yang sudah disesuaikan dengan urutan penomoran yang benar. Pada setiap bab sudah dipaparkan dengan jelas judul bab yang akan dibahas pada setiap pertemuan. Penulisan huruf pada setiap judul bab menggunakan huruf kapital dengan dicetak tebal. Pemaparan selanjutnya yang terdapat dalam buku ajar yang dikembangkan adalah pengantar. Pengantar ini merupakan bagian awal yang harus dibaca oleh siswa. Pada bagian ini disampaikan informasi singkat tentang topik pembahasan pada setiap bab yang dapat memberikan gambaran awal kepada siswa terkait materi yang akan dipelajari. Informasi yang disampaikan disajikan dengan penjelasan singkat namun informasi-informasi penting yang harus diketahui oleh siswa sudah disajikan dengan jelas pada bagian pengantar. Dalam buku yang dikembangkan juga menyajikan kosakata. Kosakata disajikan dengan menggunkan huruf romaji. Penyajian kosakata juga sudah dilengkapi gambar dengan tujuan menumbuhkan minat belajar siswa agar kosakata yang dipelajarinya mudah dipahami dan diingat. Gambar yang digunakan adalah gambar real berwarna beserta ilustrasi pada setiap penyajiannya. Sesuai dengan permintaan responden gambar yang disajikan menggunakan gambar real berwarna yang diambil dari kondisi nyata dilapangan dengan tujuan menghindari salah persepsi makna dan juga menghindari pelanggaran hak cipta gambar. Penyajian kosakata juga dilengkapi dengan arti dengan tujuan agar siswa tidak salah mengartikan kosakata yang disajikan. Dalam buku yang dikembangkan juga menyajikan pola kalimat. Penyajian pola kalimat pada setiap bab sudah disertai dengan penjelasan singkat tentang penggunaan dan fungsi pola kalimat tersebut. Untuk memastikan siswa memahami pola kalimat yang sudah dipelajarinya, pada buku ini juga disajikan latihan pola kalimat pada setiap pembahasannya. Latihan pola kalimat disajikan tanpa disertai arti dengan tujuan agar siswa secara mandiri mampu membuat sebuah pola kalimat baru sesuai dengan tata bahasa yang benar. Pola kalimat yang diajarkan adalah pola kalimat yang sudah disesuaikan dengan silabus dan sudah disesuikan dengan tingkat kemampuan siswa SMK kelas $X$ jurusan keperawatan. Pada bab 1 tidak diajarkan pola kalimat karena pada bab ini hanya khusus mempelajari ungkapanungkapan bahasa Jepang yang biasa digunakan sehari-hari. Dengan adanya penyajian pola kalimat diharapkan siswa secara mandiri bisa mengembangkan kalimat menjadi sebuah wacana ataupun dialog. Setelah penyajian pola kalimat, dalam buku ini terdapat latihan, siswa diajak untuk membuat kalimat yang benar sesuai dengan pola kalimat yang telah dipelajari sebelumnya. Terdapat juga contoh percakapan. Dalam setiap bab contoh percakapan yang sudah disesuaikan dengan komunikasi yang biasanya dilakukan oleh pasien dan perawat. Terdapat penyajian kegiatan. Kegiatan disajikan dengan tujuan agar mengetahui seberapa jauh pemahaman siswa terhadap materi yang sudah dipelajarinya. Sesuai dengan silabus dan analisis kebutuhan buku ini menyediakan berbagai jenis latihan. Jenis kegiatan yang dilakukan pada setiap latihan berbeda-beda dengan tujuan agar siswa tidak cepat jenuh dan tertarik dengan kegiatan-kegiatan yang akan dilakukannya. Latihan yang disajikan dalam buku ini seperti bermain peran, information gap, melengkapi dialog rumpang dan menjodohkan kata. Penyajian terakhir tata cara penulisan hiragana.

Hasil yang ditemukan setelah melakukan penelitian di SMK KesehatanVidya Usadha Singaraja yaitu sampai saat ini masih belum tersedianya buku ajar bahasa Jepang keperawatan untuk siswa kelas X semester ganjil. Menurut Tiagarajan, dkk (1974), analisis ujung depan bertujuan untuk memunculkan dan menetapkan masalah dasar yang dihadapi dalam pembelajaran, sehingga diperlukan suatu pengembangan bahan pembelajaran. Buku 
dirancang dikarenakan ditemukannya suatu masalah sehingga mendorong peneliti untuk mengembangkan sebuah bahan ajar yang dibutuhkan oleh responden. Begitu juga dengan permasalahan yang timbul di SMK Kesehatan Vidya Usadha Singaraja. Berdasarkan hasil wawancara yang dilakukan kepada guru mata pelajaran bahasa Jepang di SMK Kesehatan Vidya Usadha Singaraja menjelaskan bahwa sekolah masih mengalami masalah dikarenakan buku yang digunakan masih belum sesuai dengan kebutuhan siswa khususnya siswa kelas $X$ Jurusan keperawatan yang membutuhkan buku yang membahas tentang bahasa Jepang keperawatan.

Guru mata pelajaran bahasa Jepang di SMK Kesehatan Vidya Usadha Singaraja menjelaskan bahwa pengembangan buku ajar bahasa Jepang keperawatan sangat diharapkan karena pengenalan materi tentang bahasa Jepang Keperawatan sangat tepat dikenalkan di kelas $X$ khususnya Jurusan keperawatan. Selain itu alasan lain dibutuhkannya materi tentang bahasa Jepang keperawatan dikarenakan pihak sekolah SMK Vidya Usadha Singaraja sudah mendapatkan tawaran dari pihak luar berkerja sebagai perawat di Jepang Seringkali guru harus mengajarkan materi bahasa Jepang keperawatan dengan mencari sumber materi di media internet dan menghubungkannya dengan materi yang terdapat pada buku Sakura. Hal tersebut kerapkali membuat siswa kebingungan dengan materi yang diajarkan. Dengan dikembangkannya buku ini dapat memudahkan siswa memahami materi yang semestinya siswa ketahui dan juga membantu siswa mengembangkan materi tersebut dengan berpedoman pada buku ajar yang dikembangkan.

Buku ajar yang dikembangkan berpatokan dengan kurikulum dan silabus yang berlaku di SMK Kesehatan Vidya Usadha Singaraja. Kurikulum yang digunakan adalah Kurikulum Tingkat Satuan Pendidikan (KTSP). Menurut Departemen Pendidikan Nasional (dalam Sudira, 2006), Kurikulum Tingkat Satuan Pendidikan (KTSP) adalah kurikulum oprasional yang disusun oleh dan dilaksanakan di masing-masing satuan pendidikan. Silabus yang dikembangkan berpatokan pada kurikulum yang berlaku di SMK Kesehatan Vidya Usadha Singaraja. Buku dikembangkan dengan menggali kebutuhan dan standar kompetensi yang akan dipakai sebagai pedoman dalam mengembangkan buku ajar. Kebutuhan dan standar kompetensi digali dari visi misi sekolah, tujuan yang hendak dicapai siswa dalam mata pelajaran bahasa Jepang dan menganalisis kurikulum SMK Kesehatan Vidya Usadha Kesehatan.

Sampai saat ini masih belum ditemukan buku ajar bahasa Jepang keperawatan yang khusus digunakan oleh siswa SMK Kesehatan. Menurut Tiagarajan, dkk (1974), analisis siswa adalah telaah tentang karakteristik siswa yang sesuai dengan desain pengembangan perangat pembelajaran. Buku ini dikembangkan dengan tujuan agar sesuai dengan kebutuhan siswa. Pengembangan buku ajar bahasa Jepang keperawatan sudah disesuikan dengan karakteristik siswa lewat hasil angket yang sudah diisi oleh siswa kelas $\mathrm{X}$ semester ganjil jurusan keperawatan..

Secara umum manfaat dari buku ini antara lain, 1) Kebutuhan bahan ajar yang berupa buku ajar bahasa Jepang keperawatan dapat membantu pebelajar khususnya SMK Kesehatan Vidya Usadha Sinagaraja yang menawarkan program kesehatan/jurusan keperawatan, 2) Saat proses belajar mengajar,guru tidak perlu mencari bukuatau materi bahasa Jepang untuk keperawatan karena belum tentu materiyang didapatkan sesuai dengan level siswa SMK.

\section{Simpulan dan Saran}

Berdasarkan hasil dan pembahasan penelitian yang diuraikan, maka dapat disimpulkan yaitu buku ajar bahasa Jepang keperawatan 1 untuk siswa kelas $X$ semester ganjil di SMK Kesehatan Vidya Usadha Singaraja. Buku yang dikembangkan terdiri dari 10 bab dengan menyajikan pengantar, kosakata, pola kalimat, contoh percakapan, kegiatan dan penulisan huruf hiragana. Pada bagian pengantar memberikan informasi singkat terkait materi yang di pelajari. Informasi tersebut memberikan gambaran awal yang dapat memberikan informasi penting kepada pebelajar mengenai kegiatan yang dilakukan di dalam rumah sakit. Kosakata dalam buku ini disajikan dengan dilengkapi gambar real berwarna. Pada bagian penyajian pola kalimat menyajikan penjelasan pola kalimat bahasa Jepang keperawatan. Selain itu juga 
disajikan latihan pola kalimat agar siswa secara mandiri dapat mengembangkan sebuah kalimat baru. Selanjutnya menyajikan kegiatan. Jenis kegiatan yang disajikan pada buku ini diantaranya yaitu role play, information gap, menjodohkan kata, mendegarkan CD, dan melengkapi dialog rumpang. Diharapkan dengan dikembangnkannya buku ini dapat membantu guru dan siswa khusunya di SMK Vidya Usadha Singaraja agar memiliki buku yang sesuai dengan materi yang diajarkan untuk siswa kelas $X$ semseter ganjil jurusan keperawatan. Buku ajar bahasa Jepang selanjutnya diharapkan dapat menyajikan cakuoan materi lebih luas mengenai materi bahasa Jepang kesehatan. Kemudian di dalam buku diharapkan terdapat latihan-latihan yang lebih bervariasi dalam membantu pembelajaran bahasa Jepang di bidang kesehatan, serta menyusun buku yang lebih baik, menarik dan inovatif.

\section{Daftar Pustaka}

AbdelWahab, Dr.Montaser Mohamed. 2013. "Developing an English Language Textbook Evaluative Checklist". IOSR Journal of Research \& Method in Education, Volume 1, Issue 3 (hlm.55-70)

Bungin, Burhan. 2005. Metodelogi Penelitian Kuantitatif. Jakarta: Kencana Prenada Media Group

Depdiknas Direktorat Jendral Menejemen Pendidikan Dasar dan Menengah. 2008. Panduan Pengembangan Bahan Ajar. Jakarta: Depdiknas.

Dwicahyo, Daryanto Aris. 2014. Pengembangan Perangkat Pembelajaran. Cetakan pertama Yogyakarta: Gava Media.

Efendhi, Elvas Sugianto, dkk. 2014. "Pengembangan Bahan Ajar Buku Berjendela Sebagai Pendukung Implementasi Pembelajaran Berbasis Scientific Approach Pada Materi Jurnal Khusus". Tersedia Pada:http://jurnalmahasiswa.unesa.ac.id/article/12501/52/article.pdf. (diakses tanggal 18 Januari 2018)

Hutman, F. S. 2008. "Pengembangan Bahan Ajar IPS Berbasis Nilai Budaya Using Untuk Siswa Sekolah Dasar". Tersedia pada https://ejournal.undiksha.ac.id/index.php/JPI/article/view/8359/5838. Volume 5, Nomer 2. (diakses tanggal 18 Januari 2018)

Isnawati, dkk.2012. "Pengembangan Buku Ajar Materi Bioteknologi Di Kelas XII SMA IPEMS Surabaya Berorientasi Sain, Teknologi, Lingkungan, dan Masyarakat (SETS)". Tesedia pada:http://ejournal.unesa.ac.id/index.php/bioedu.html (diakses tanggal 12 Agustus 2017)

Ningsih dkk. 2009. Sakura 1. Jakarta: The Japan Foundation.

Priyanto, 2015. Komunikasi dan Sikap Empati dalam Keperawatan. Cetakan pertama. Yogyakarta: Graha Ilmu.

Padmadewi, Ni Nyoman. 2012. Strategi Pembelajaran Bahasa. Singaraja: Undiksha.

Paizaluddin dan Ermalinda. 2014. Penelitian Tindak Kelas. Bandung: Alfabeta.

Sugiyono. 2009. Metode Penelitian Kuantitatif Kualitatif dan R\&D. Cetakan ketujuh. Bandung: CV Afabet. 
Sudaryono dkk. 2013. Pengembangan Instrumen Penelitian Pendidikan. Cetakan Pertama. Yogyakarta: Graha IImu.

Sudira, Putu. 2006. Kurikulum Tingkat Satuan Pendidikan. Tersedia pada: http://webcache.googleusercontent.com/search?q=cache:53rG0gRKaO4J:staff.uny.ac.i $\mathrm{d} /$ sites/default/file/tmp/bukuktsp. $p d f+\& c d=1 \& c t=c l n k \& g l=i d . \quad$ (diakses pada Tanggal 17 Januari 2018)

Sukerni, Putu. 2014. "Pengembangan Buku Ajar Pendidikan Ipa Kelas Iv Semester I Sd No. 4 Kaliuntu Dengan Model Dick and Carey". Tersedia pada:https://ejournal.undiksha.ac.id/index.php/JPI/article/view/2920/2420. Universitas Pendidikan Ganesha, Volume 3, Nomor 1 (hlm.387-396) (diakses Tanggal 20 Desember 2017)

Thiagarajan, S., Sammel, D. S \& Samel, M. I. 1974. Instructional Development for Training Teachers of Expectional Chidren. Minneapolis, Minnesota: Leadership Training Institute/Special Education, University of Minnesota.

Undang-undang Republik Indonesia No.2 Tahun 1989 tentang Sistem Pendidikan Nasional, 1990. Jakarta: PT Arnas Duta Jaya. 